\title{
Meningkatkan Motivasi dan Hasil Belajar Mahasiswa Melalui Model Pembelajaran Kooperatif Group Investigation Pada Mata Kuliah Psikologi Pendidikan di Program Studi Pendidikan Agama Islam FAI UMSU 2016-2017
}

\author{
Hasrian Rudi Setiawan dan Widya Masitah \\ Dosen Fakultas Agama Islam UMSU \\ (Email : hasrianrudisetiawan@gmail.com)
}

\begin{abstract}
ABSTRAK
Penelitian ini memiliki tujuan jangka panjang yaitu untuk meningkatkan motivasi dan hasil belajar mahasiswa serta mempengaruhi pola pikir mahasiswa agar senang belajar secara berkelompok, yang diharapkan dapat menumbuhkan sikap sosial, rasa percaya diri, menumbuhkan semangat, berfikir kreatif dan inovatif. Jenis penelitian ini adalah penelitian tindakan kelas. Adapun penelitian ini dilakukan dengan langkah-langkah yaitu: 1). Melakukan persiapan terhadap penelitian yang akan dilaksanakan; 2). Merencanakan tindakan yang akan dilakukan selama proses penelitian; 3). Melaksanakan tindakan di kelas sekaligus melakukan observasi atau pengamatan langsung; 4). Refleksi. Adapun hasil penelitian ini secara umum, yaitu: Pertama, Hasil belajar mahasiswa Program Studi Pendidikan Agama Islam Semester II Universitas Muhammadiyah Sumatera Utara mengalami peningkatan setelah menggunakan model pembelajaran kooperatif group investigation, yaitu hasil belajar mahasiswa pada pra tindaan hanya 10 orang mahasiswa yang mendapat nilai tuntas atau mencapai $41.67 \%$. Sedangkan pada siklus I hasil belajar mahasiswa mengalami peningkatan dibandingkan dengan kegiatan pra tindakan, yaitu mencapai 22 orang mahasiswa yang mendapat nilai tuntas atau mencapai 91,67\%. Kedua, Motivasi mahasiswa terhadap pembelajaran dengan menggunakan model pembelajaran kooperatif group investigation di Program Studi Pendidikan Agama Islam Universitas Muhammadiyah Sumatera Utara menunjukkan kondisi positif dan menggembirakan, yang sebelumnya pada kegitan pra tindakan menunjukkan motivasi belajar siswa, yaitu 66.67\%, sedangkan pada siklus kedua mengalami peningkatan, yaitu: $81.88 \%$

Key words: Motivasi, Hasil Belajar, Model Pembelajaran Kooperatif Group Investigation

\section{A. PENDAHULUAN}

\subsection{Latar Belakang Masalah}

Mata kuliah psikologi pendidikan merupakan salah satu mata kuliah yang diajarkan di Fakultas Agama Islam pada Program Studi Pendidikan Agama Islam. Mata kuliah ini di rasakan sebagai mata kuliah yang sulit bagi mahasiswa, karena

psikologi pendidikan membahas tentag masalah yang berkaitan dengan persoalan-persoalan yang berkaitan dengan proses dan faktor-faktor yang berhubungan dengan tindakan belajar. Dalam mata kuliah psikologi pendidikan mahasiswa dituntut untuk dapat menguasai pokok bahasan psikologi pendidikan, yang meliputi:
\end{abstract}


Pertama, pembehasan mengenai belajar, yang meliputi teori-teori, prinsip-prinsip dan ciri-ciri khas perilaku belajar siswa. Kedua, pembahasan mengenai proses belajar, yakni tahapan perbuatan dan peristiwa yang terjadi dalam kegiatan belajar siswa. Ketiga, pembahasan mengenai situasi belajar, yakni suasana dan keadaan lingkungan baik bersifat fisik maupun non fisik yang berhubungan dengan belajar siswa sampai kepada evaluasi pembelajaran siswa.

$$
\text { Keberhasilan }
$$

proses

pembelajaran dalam kegiatan pendidikan pada dasarnya dipengaruhi oleh banyak faktor, di antaranya adalah dosen, mahasiswa, lingkungan, kurikulum, strategi, metode dan media pembelajaran yang efektif yang dapat membantu mahasiswa agar dapat belajar secara optimal dan mampu meningkatkan motivasi dan hasil belajar mahasiswa. Untuk menciptakan pembelajaran yang menarik, dosen harus memilih model, stategi, metode dan media pembelajaran yang tepat sesuai dengan materi perkuliahan yang diajarkan.

Keberhasilan suatu perkuliahan sangat tergantung dari kemampuan mahasiswa dalam menguasai materi perkuliahan tertentu, mahasiswa dikatakan menguasai materi perkuliahan apabila hasil belajar mahasiswa minimal mendapat nilai 75 atau mendapat nilai B. Artinya dalam pelaksanaan perkuliahan pada mata kuliah psikologi pendidikan dikatakan berhasil apabila mahasiswa secara individu mendapatkan nilai 75 atau mendapatkan nilai B. Dan dosen dikatakan berhasil mengajarkan mata kuliah psikologi pendidikan apabila $80 \%$ dari jumlah mahasiswa dalam kelas tersebut mendapat nilai 75 .

Berdasarkan pengamatan penulis, menurut informasi dari Dekan Fakultas Agama Islam, Ketua Prodi Pendidikan Agama Islam dan dosen mata kuliah psikologi pendidikan. Kondisi yang dialami oleh mahasiswa adalah kesulitan menerima penjelasan yang disampaikan oleh dosen dan kurangnya minat mahasiswa dalam mengikuti mata perkuliahan psikologi pendidikan, yang ditandai dengan sikap, tingkah laku, dan kebosanan dalam mengikuti perkuliahan, yaitu cuek, keluar masuk ruangan perkuliahan, melamun, mencoret-coret kertas, mengantuk, mengerjakan pekerjaan lain, dan mengganggu mahasiswa lain. 
Apalagi banyak mahasiswa yang cenderung belum dapat memahami materi evaluasi pembelajaran yang merupakan salah satu di antara materi perkuliahan psikologi pendidikan yang wajib diketahui. Hal ini terlihat dari banyaknya mahasiswa yang mengikuti ujian, baik itu Ujian Tengah Semester (UTS) dan Ujian Akhir Semester (UAS), mendapat nilai rendah.

\section{Berdasarkan kondisi yang} dialami oleh mahasiswa di Prodi Pendidikan Agama Islam menunjukkan bahwa motivasi dan hasil belajar dalam mata kuliah psikologi pendidikan cenderung kurang maksimal. Salah satu faktor penyebab utama dari kebosanan belajar mata kuliah psikologi pendidikan, bukan karena tidak bermutunya materi yang disampaikan, akan tetapi banyak disebabkan oleh kegagalan dosen dalam mempergunakan model, stategi, metode, media pembelajaran atau pendekatan yang dipakai.

Berdasarkan hal tersebut,
penulis memilih solusi masalah
rendahnya motivasi dan hasil belajar
mahasiswa dalam mata kuliah
psikologi pendidikan pada materi
evaluasi pembelajaran yaitu dengan

menggunakan model pembelajaran kooperatif group investigation. Dan juga dapat dilakukan dengan dukungan media pembelajaran. Dengan memperhatikan uraian di atas dan dalam rangka mengatasi permasalahan rendahnya motivasi dan hasil belajar mahasiswa dalam mata kuliah psikologi pendidikan, maka dipergunakan Penelitian Tindakan Kelas (PTK) pada materi evaluasi pebelajaran karena itu peneliti akan mengadakan penelitian melalui sebuah penelitian dengan judul: "Meningkatkan Motivasi dan Hasil Belajar Mahasiswa Melalui Model Pembelajaran Kooperatif Group Investigation Pada Mata Kuliah Psikologi Pendidikan di Program Studi Pendidikan Agama Islam FAI UMSU 2016-2017”.

\subsection{Rumusan Masalah}

Rumusan masalah yang digunakan dalam penelitian ini adalah:

1. Bagaimana motivasi belajar mahasiswa sesudah menggunakan model Pembelajaran kooperatif group investigation pada mata kuliah psikologi pendidikan materi evaluasi pembelajaran di Program Studi Pendidikan Agama Islam Universitas Muhammadiyah Sumatera Utara? 
2. Bagaimana hasil belajar mahasiswa sesudah menggunakan model Pembelajaran kooperatif group investigation pada mata kuliah psikologi pendidikan materi evaluasi pembelajaran di Program Studi Pendidikan Agama Islam Universitas Muhammadiyah Sumatera Utara?

3. Bagaimana tanggapan mahasiswa terhadap penggunaan model Pembelajaran kooperatif group investigation dalam meningkatkan motivasi dan hasil belajar mahasiswa pada mata kuliah psikologi pendidikan materi evaluasi pembelajaran di Program Studi Pendidikan Agama Islam Universitas Muhammadiyah Sumatera Utara?

\subsection{Tujuan Penelitian}

Penelitian ini secara umum memiliki tujuan untuk meningkatkan motivasi dan hasil belajar mahasiswa melalui model pembelajaran kooperatif group investigation pada mata kuliah psikologi pendidikan materi evaluasi pembelajaran di Program Studi Pendidikan Agama Islam Universitas Muhammadiyah Sumatera Utara.Sedangkan secara khusus, penelitian ini bertujuan untuk:
1. Membantu mahasiswa mengeksplorasi diri dalam mengembangkan kompetensi yang ada pada dirinya.

2. Membantu mahasiswa dalam meningkatkan motivasi belajar pada mata kuliah psikologi pendidikan pada materi evaluasi pembelajaran di Program Studi Pendidikan Agama Islam Universitas Muhammadiyah Sumatera Utara.

3. Membantu mahasiswa mencapai hasil belajar yang memuaskan, khususnya di Program Studi Pendidikan Agama Islam Universitas Muhammadiyah Sumatera Utara.

4. Memperkenalkan penerapan model pembelajaran kooperatif group investigation kepada mahasiswa.

\section{B. KAJIAN PUSTAKA}

\subsection{Motivasi Belajar}

\subsubsection{Pengertian Motivasi Belajar}

Motivasi berasal dari bahasa Latin yaitu dari kata movere yang bermakna bergerak, istilah ini memiliki makna mendorong, mengarahkan tingkah laku manusia. ${ }^{1}$

\footnotetext{
${ }^{1}$ Iskandar, Psikologi Pendidikan Sebuah Orientasi Baru. (Ciputat: Gaung Persada Press, 2009). h. 15.
} 
Motivasi merupakan segala sesuatu yang menjadi pendorong tingkah laku yang menuntut atau mendorong seseorang untuk memenuhi kebutuhan. ${ }^{2}$

Menurut Hamzah B. Uno, motivasi belajar adalah dorongan internal dan eksternal pada peserta didik yang sedang belajar untuk mendapatkan perubahan tingkah laku dengan beberapa indikator, yaitu adanya keinginan berhasil, adanya dorongan dan kebutuhan dalam belajar, adanya harapan dan cita-cita masa depan, adanya penghargaan, adanya kegiatan yang menarik dalam belajar dan adanya lingkungan belajar yang kondusif sehingga memungkinkan seseorang peserta didik dapat belajar dengan baik. ${ }^{3}$

Dapat pengertian di atas dapat dipahami bahwa, motivasi dalam belajar merupakan daya penggerak dari dalam diri individu untuk melakukan kegiatan belajar untuk menambah pengetahuan dan keterampilan serta pengalaman. Motivasi juga dapat dipahami sebagai

2 Rusman, Model-Model Pembelajaran, (Jakarta: PT. Raja Grafindo Persada, 2010). h. 23.

3 Hamzah B. Uno, Teori Motivasi dan Pengukurannya: Analisis Di Bidang Pendidikan, (Jakarta: Bumi Aksara, 2010). h. 38. proses untuk mencoba mempengaruhi orang atau orang-orang yang dipimpinnya agar melakukan pekerjaan yang diinginkan, sesuai dengan tujuan tertentu yang ditetapkan lebih dahulu.

\subsubsection{Sumber-sumber Motivasi dalam Pembelajaran}

Dalam kegiatan belajar ada dua jenis sumber motivasi, yaitu: Pertama, Motivasi Internal (Intrinsik Motivation) merupakan motivasi yang timbul dalam diri peserta didik sendiri, tanpa adanya pengaruh dari luar individu. ${ }^{4}$ Apabila mahasiswa yang telah memiliki motivasi internal dalam dirinya, maka secara sadar daya dorong seseorang individu sebagai kekuatan untuk melakukan aktivitas belajar yang berhubungan dengan kebutuhan.

Kedua, Motivasi Eksternal (Ekstrinsik Motivation) adalah dorongan dari luar diri, tindakan atau perbuatan yang didasari oleh dorongan-dorongan yang bersumber dari luar pribadi seseorang (lingkungan) untuk melakukan sesuatu karena adanya paksaan dari

\footnotetext{
4 Ngalim Purwanto, Psikologi Pendidikan, (Bandung: Remaja Rosdakarya, 2004). h. 67.
} 
luar. ${ }^{5}$ Jenis motivasi ini timbul akibat pengaruh individu, apakah karena adanya ajakan, suruhan atau paksaan dari orang lain sehingga dengan kondisi yang demikian akhirnya seseorang mau melakukan sesuatu atau belajar. ${ }^{6}$

\subsubsection{Peran dan Fungsi Motivasi dalam Proses Pembelajaran}

Kegiatan belajar sangat

memerlukan motivasi, karena hasil belajar akan menjadi optimal, kalau ada motivasi. Semangkin baik motivasi yang diberikan, maka akan semangkin berhasil pula pelajaran yang dipelajarinya. Adapun di antara peran motivasi dalam proses pembelajaran adalah: 1). Memberikan semangat dan mengaktifkan peserta didik agar tetap berminat; 2). Membantu memenuhi kebutuhan akan hasil jangka pendek dan hasil jangka panjang; 3). Membantu memusatkan perhatian peserta didik pada tugastugas tertentu yang berhubungan dengan pencapaian tujuan belajar . ${ }^{7}$

5 Sudarsono, Kamus Filsafat dan Psikologi, (Jakarta: Rineka Cipta, 2004). h. 45.

${ }^{6}$ Hamdani, Strategi Belajar Mengajar, (Bandung: CV. Pustaka Setia, 2010), h. 29.

7 Zakiah Daradjat, Metodik Khusus Pengajaran Agama Islam, (Jakarta: Bumi Aksara, 2008), h. 26.
Sedangkan fungsi motivasi yang berkenaan dengan proses belajar mengajar, adalah: Pertama, Fungsi penggerak, yaitu penggerak atau pendorong untuk melakukan kegiatan belajar peserta didik. Kedua, Fungsi harapan, yaitu dosen memberikan harapan-harapan tersebut untuk menggugah motivasi belajar. ${ }^{8}$

\subsubsection{Metode Pendidik dalam Memotivasi Peserta Didik Untuk Belajar}

Pendidik memiliki peran yang sangat besar dalam memotivasi belajar peserta didik. Selain pendidik, orang tua, masyarakat dan teman juga sangat berperan aktif dalam menumbuhkan motivasi belajar peserta didik. Beberapa metode motivasi yang dapat dilakukan dalam pembelajaran, di antaranya: 1). Memberikan penghargaan dengan menggunakan kata-kata, seperti ucapan bagus sekali, hebat, menakjubkan, dan lain sebagainya; 2). Memberikan nilai ulangan sebagai pemacu bagi peserta didik untuk belajar lebih giat; 3). Mengadakan permainan dan menggunakan simulasi; 4). Menumbuhkan dan menimbulkan rasa ingin tahu dalam diri peserta didik.

\footnotetext{
${ }^{8}$ Hamdani, Strategi Belajar Mengajar, (Bandung: CV. Pustaka Setia, 2010), h. 29.
} 
Rasa ingin tahu dapat ditimbulkan oleh suasana yang tiba-tiba atau mengejutkan; 5). Menumbukhan persaingan antara peserta didik; 6). Memberikan contoh dan sikap yang positif, artinya dalam memberikan pekerjaan kepada peserta didik dosen tidak dibenarkan meninggalkan ruangan untuk melaksanakan pekerjaan yang lain; 7). Penampilan seorang pendidik, artinya penampilan seorang pendidik yang bersih, rapih, sopan, dan menarik akan memotivasi peserta didik dalam mengikuti pelajaran. Termasuk juga kepribadian pendidik, pendidik yang masuk kelas dengan wajah tersenyum akan membuat peserta didik senang mengikuti pelajaran yang sedang berlangsung. ${ }^{9}$

\subsection{Hasil Belajar Mahasiswa}

\subsubsection{Pengertian Hasil Belajar}

Kemampuan yang dimiliki mahasiswa dari proses belajar harus dapat mendapatkan hasil. Karena itu, hasil belajar yang dimaksud di sini adalah kemampuan-kemampuan yang dimiliki seorang mahasiswa setelah peserta didik menerima perlakukan dari dosen selaku pendidik. Menurut

9 Zakiah Daradjat, Metodik Khusus Pengajaran Agama Islam, (Jakarta: Bumi Aksara, 2008), h. 76.
Nana Sudjana, hasil belajar adalah kemampuan-kemampuan yang dimiliki mahasiswa setelah menerima pengalaman belajarnya. ${ }^{10}$

Dari definisi di atas, dapat dipahami bahwa hasil belajar adalah merupakan hasil dan bukti belajar seseorang yang ditunjukkan dengan adanya perubahan tingkah laku. Hasil belajar akan tampak pada setiap perubahan pada aspek-aspek tersebut, baik dari salah satu aspek atau beberapa aspek.

\subsubsection{Faktor-faktor Yang Mempengaruhi Hasil Belajar} Mahasiswa

Secara umum ada dua faktor yang mempengaruhi hasil belajar yang dicapai oleh mahasiswa, di antaranya adalah: Pertama, Faktor internal yaitu dari sisi diri peserta didik, terdapat dua hal yang dapat mempengaruhi aktivitas dan hasil belajarnya, yaitu kondisi psikologis dan fisiologis. Kondisi psikologis adalah keadaan jiwa atau ruhaninya. Sedangkan kondisi fisiologis merupakan kondisi fisik, jasmani, atau tubuh peserta didik yang belajar. Kedua, Faktor eksternal yaitu segala sesuatu yang berasal dari

\footnotetext{
10 Nana Sudjana, Penilaian Hasil Proses Belajar Mengajar (Bandung: PT. Remaja Rosdakarya, 2006), h. 54.
} 
luar diri peserta didik yang dapat mempengaruhi aktivitas dan hasil belajarnya.

\subsubsection{Evaluasi Belajar}

Evaluasi hasil belajar adalah suatu proses yang sistematis dan berkelanjutan untuk menentukan kualitas daripada sesuatu, berdasarkan pertimbangan dan kriteria tertentu untuk membuat suatu keputusan. ${ }^{11}$ Untuk melihat hasil belajar mahasiswa meningkat atau tidak, maka dosen hendaknya melakukan evaluasi terhadap hasil belajar mahasiswa. Karena itu, evaluasi memiliki manfaat di antaranya: 1). Untuk mengetahui tingkat penguasaan peserta didik terhadap materi yang telah diberikan; 2). Untuk mengetahui tingkat kemajuan dan kesesuaian hasil belajar peserta didik dengan standar kompetensi dan kompetensi dasar yang telah ditetapkan; 3). Untuk mengetahui kecakapan, motivasi, bakat, minat, dan sikap peserta didik terhadap program pembelajaran; 4). Untuk seleksi, yaitu memilih dan menentukan peserta didik yang sesuai dengan jenis pendidikan tertentu; 5). Untuk menentukan kenaikan kelas; 6). Untuk mendiagnosis keunggulan dan

\footnotetext{
${ }^{11}$ Zainal Arifin, Evaluasi Pembelajaran. (Jakarta: Direktorat Jendral Pendidikan Islam Kementrian Agama, 2012), h. 43.
}

kelemahan peserta didik dalam mengikuti kegiatan pembelajaran; 7). Untuk menempatkan peserta didik sesuai dengan potensi yang dimilikinya. $^{12}$

Dalam pelaksanaan evaluasi, secara umum tes hasil belajar dapat dibedakan menjadi dua macam, yaitu: Pertama, Tes formatif adalah tes yang diadakan sebelum atau selama pelajaran berlangsung. Tes formatif ini mempunyai dua tujuan, yaitu untuk membantu dosen dalam membuat perencanaan dan untuk membantu mahasiswa mengenali segi-segi yang perlu ditanggani. ${ }^{13}$ Kedua, Tes sumatif adalah tes yang diselenggarakan pada akhir seluruh kegiatan belajar mengajar. Tujuannya adalah untuk memberi tahu dosen dan mahasiswa tentang seberapa jauh yang telah dicapai selama satu triwulan dan selama satu semester. ${ }^{14}$

\subsection{Model Pembelajaran Kooperatif Group Investigation}

Pembelajaran kooperatif

\footnotetext{
12 Iskandar, Psikologi Pendidikan Sebuah Orientasi Baru. Ciputat: Gaung Persada Press, 2009), h. 56.

${ }^{13}$ Ngalim Purwanto, Prinsip-Prinsip dan Teknik Evaluasi Pengajaran. (Bandung: Rosdakarya. 2005), h. 42.

${ }^{14}$ Rosnita, Evaluasi Pendidikan. (Bandung: Ciptapustaka Media, 2007), h. 32.
} 
merupakan bentuk pembelajaran dengan cara siswa belajar dan bekerja dalam kelompok kecil secara kolaboratif yang anggotanya terdiri dari emapat sampai enam orang dengan struktur kelompok yang bersifat heterogen. ${ }^{15}$ Model pembelajaran kooperatif group investigation menurut Sumarmi merupakan pembelajaran kooperatif yang melibatkan kelompok kecil, siswa menggunakan inkuiri kooperatif (perencanaan dan diskusi kelompok) kemudian mempresentasikan penemuan mereka di kelas. ${ }^{16}$ Model pembelajaran kooperatif group investigation ini melatih mahasiswa untuk membangun kemampuan berfikir secara mandiri dan kritis serta melatih mahasiswa dalam menyelesaikan suatu permasalahan dalam kelompok.

\subsubsection{Kelebihan}

Model

\section{Pembelajaran Kooperatif} Group Investigation

Model pembelajaran kooperatif group investigation

15 Rusman, Model-Model Pembelajaran, (Jakarta: PT. Raja Grafindo Persada, 2010), h. 34.

16 Suharsimi Arikunto, Prosedur Penelitian. (Jakarta: PT. Rineka Cipta, 2002), h. 43 . memiliki beberapa kelebihan dibandingkan dengan model pembelajaran kooperatif lainnya, di antara kelebihannya adalah: 1). Mahasiswa yang berpartisipasi dalam group investigasi cenderung berdiskusi dan menyumbangkan ideide tertentu; 2). Gaya bicara dan kerjasama mahasiswa dapat diobservasi; 3). Mahasiswa dapat belajar berkelompok lebih efektif, dengan demikian dapat meningkatkan interaksi sosial dicantara mereka; 4). Dapat mendorong mahasiswa untuk berpartisipasi aktif, sehingga pengetahuan yang diperoleh dapat ditransfer ke situasi diluar kelas; 5). Mengijinkan dosen untuk lebih informal; 6). Dapat meningkatkan penampilan dan prestasi belajar siswa. $^{17}$

\subsubsection{Langkah Pelaksanaan Model Pembelajaran Kooperatif Group Investigation}

Adapun langkah-langkah pembelajaran kooperatif group investigation, di antaranya adalah: 1). Membagi mahasiswa ke dalam kelompok kecil yang terdiri dari \pm 5 orang mahasiswa; 2). Memberikan

${ }^{17}$ Sumarmi, Model-Model Pembelajaran Geografi, (Malang: Aditya Media, 2012), h. 48. 
pertanyaan terbuka yang bersifat analitis; 3). Mengajak setiap mahasiswa untuk berpartisipasi dalam menjawab pertanyaan kelompoknya secara bergiliran searah jarum jam dalam kurun waktu yang disepakati. ${ }^{18}$

Selain itu pula model pembelajaran kooperatif group investigation, dapat dilakukan dengan langkah-langkah sebagai berikut: 1). Mengidentifikasi topik dan mengorganisasikan mahasiswa ke dalam kelompok. Dalam hal ini mahasiswa menelaah sumber-sumber informasi, memilih topik, dan mengategorisasi saran-saran; para mahasiswa bergabung ke dalam kelompok didasarkan atas ketertarikan topik yang sama dan heterogen; guru membantu dan memfasilitasi dalam memperoleh informasi; 2). Merencanakan tugas-tugas pembelajaran, yaitu direncanakan secara bersama-sama oleh para mahasiswa dalam kelompoknyamasing-masing, yang meliputi: “apa yang kita selidiki, bagaimana kita melakukannya, siapa yang membahas bagian ini, dan untuk tujuan apa topic ini di investigasi”; 3).

\footnotetext{
18 Rusman. Model-Model Pembelajaran. Jakarta: PT. Raja Grafindo Persada, 2010), h.56.
}

Melaksanakan investigasi, yaitu mahasiswa mencari informasi, menganalisis data, dan membuat kesimpulan. Dalam hal ini setiap anggota kelompok harus berkontribusi kepada usaha kelompok, bertukar pikiran, mendiskusikan, mengklarifikasi, dan mensintesis ideide; 4). Menyiapkan laporan akhir, yaitu dalam hal ini setiap kelompok merencanakan apa yang akan dilaporkan dan bagaimana membuat presentasinya dan membentuk panitia acara untuk mengoordinasikan rencana presentasi; 5). Mempresentasikan laporan akhir; 6). Evaluasi.

\section{METODE PENELITIAN}

\subsection{Lokasi dan Waktu Penelitian}

Penelitian ini dilaksanakan di Program Studi Pendidikan Agama Islam Universitas Muhammadiyah Sumatera Utara pada mata kuliah psikologi pendidikan yang dikhususkan pada materi evaluasi pembelajaran. Penelitian ini dilaksanakan dari bulan Oktober 2016 sampai Mei 2017. Penentuan waktu ini mengacu kepada kalender akademik Universitas Muhammadiyah Sumatera Utara, karena penelitian tindakan kelas memerlukan beberapa siklus yang harus menyesuaikan 
dengan program pembelajaran.

\subsection{Subjek Penelitian}

Adapun yang menjadi subjek penelitian dalam Penelitian Tindakan Kelas (PTK) ini adalah mahasiswa Program Studi Pendidikan Agama Islam UMSU yang berjumlah 40 orang, terdiri dari 16 orang laki-laki dan 24 orang perempuan di Program Studi Pendidikan Agama Islam Fakultas Agama Islam UMSU.

\subsection{Jenis Penelitian}

Bentuk penelitian ini adalah Penelitian Tindakan Kelas (PTK), yaitu suatu penelitian yang memberikan tindakan ke pada objek penelitian, yang dilakukan dengan siklus yang berkelanjutan samapi tujuan penelitian tercapai. Prosedur tindakan persiklusnya digambarkan dalam daur ulang skema berikut:

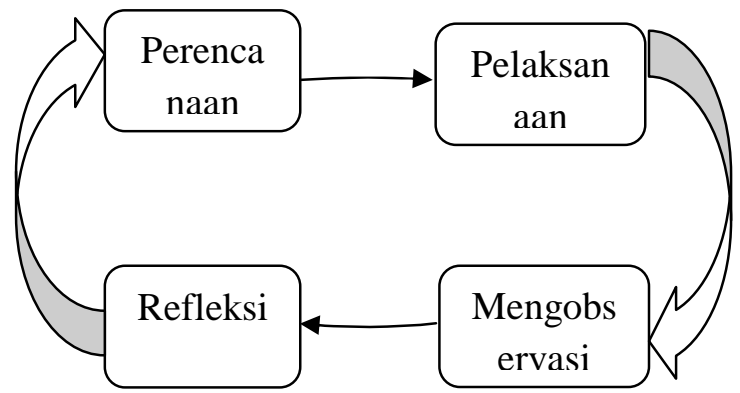

\subsection{Teknik Penggumpulan Data}

Teknik pengumpulan data adalah mengamati variabel yang diteliti dengan menggunakan metode tertentu (Arikunto, 2002). Teknik pengumpulan data dalam penelitian ini adalah:

1. Tes, digunakan untuk mendapatkan data mengenai hasil belajar mahasiswa.

2. Dokumentasi, digunakan dalam penelitian ini adalah nilai ujian mata kuliah psikologi pendidikan mahasiswa Program Studi Pendidikan Agama Islam UMSU. Metode dokumentasi dalam penelitian ini digunakan untuk mengetahui kondisi awal mahasiswa.

3. Observasi, digunakan untuk mengumpulkan data tentang motivasi mahasiswa dengan menggunakan model pembelajaran kooperatif group investigation.

Untuk menguji validitas data maka digunakan teknik triangulasi data, yaitu: 1). Triangulasi sumber data, yaitu teknik untuk menguji kebenaran dengan mengacu kebenaran data yang telah di peroleh dari satu informan dengan informan lain. Dalam penelitian ini peneliti menggunakan data dokumen yang berupa foto kegiatan pembelajaran; 2). Triangulasi 
metode, yaitu teknik yang digunakan untuk mengguji kebenaran untuk membandingkan data yang diperoleh; 3). Triangulasi teori, yaitu digunakan dengan menggunakan lebih dari satu teori dalam membahas masalah yang sedang dikaji.

\subsection{Teknik Analisis Data}

Analisis data adalah proses pengorganisasian data ke dalam pola, kategori dan satuan uraian dasar, sehingga dapat ditemukan tema seperti yang disarankan oleh data". (Moleong, 2003). Dalam pelaksanaan Penelitian Tindakan Kelas (PTK) ini terdapat dua jenis data yang dapat dikumpulkan oleh peneliti, yaitu data kualitatif dan data kuantitatif.

Adapun teknik analisis data yang digunakan dalam penelitian ini yaitu analisis deskriptif. Dalam analisis deskriptif, ada empat alur kegiatan yang menjadi satu kesatuan yang tidak dapat terpisahkan, yaitu: 1). Penggumpulan data, yaitu menggumpulkan semua data dari lapangan; 2). Reduksi data yaitu, pada teknik ini peneliti melakukan proses pemilahan data yang relevan, penting dan bermakna mulai dari awal pengumpulan data hingga peneliti melakukan penyusunan laporan penelitian; 3). Penyajian data yaitu, teknik ini memaparkan hasil temuan secara narasi. Penyajian data dilakukan dalam rangka pengorganisasian hasil reduksi dengan cara menyusun secara naratif sekumpulan informasi yang telah diperoleh dari hasil reduksi, sehingga data dapat disimpulkan dan selanjutnya dapat diberikan tindakan; 4). Penarikan kesimpulan yaitu, memberikan kesimpulan terhadap hasil penafsiran dan evaluasi. Kegiatan ini mencakup pencarian makna data dan memberi pejelasaan. Selanjutnya kemudian dilakukan verifikasi, yaitu pengujian kebenaran, kekokohan dan mencocokkan maknamakna yang muncul dari data. (Sutopo, 2002).

Dalam Penelitian Tindakan Kelas (PTK), cara kerjanya diwujudkan dalam beberapa siklus hingga tujuan pembelajaran tercapai sesuai dengan yang di harapkan, artinya penelitian (siklus) akan di hentikan apabila tujuan pembelajaran telah tercapai. Pada setiap siklus terdapat empat kegiatan, yaitu perencanaan, pelaksanaan, observasi Selanjutnya data hasil penelitian tersebut akan dianalisis sebagai berikut, yaitu: 1). Hasil 
observasi terhadap motivasi belajar mahasiswa dengan menggunakan model pembelajaran kooperatif group investigation dianalisis secara deskriptif dan data kuantitatif menggunakan persentase. 2). Hasil belajar peserta didik dianalisis dengan menggunakan prinsip konversi lima, yaitu:

$\begin{array}{ll}93-100 & =\text { Sangat Tinggi } \\ 84-92 & =\text { Tinggi } \\ 75-83 & =\text { Sedang } \\ 74-70 & =\text { Cukup } \\ 0-69 & =\text { Rendah }\end{array}$

Kriteria ideal ketuntasan belajar minimal yang ditetapkan Program Studi Pendidikan Agama Islam Universitas Muhammadiyah Sumatera Utara mata kuliah psikologi pendidikan adalah 75 sedangkan ketuntasan klasikal tercapai bila terdapat $85 \%$ mahasiswa yang tuntas belajar.

\section{HASIL DAN PEMBAHASAN}

\subsection{Deskripsi Hasil Penelitian}

\section{Pra Tindakan}

Jumlah mahasiswa Program Studi

Pendidikan Agama Islam Fakultas Agama Islam UMSU berjumlaah 24 orang. Setelah dilakukan kegiatan perkuliahan pada mata kuliah psikologi pendidikan materi evaluasi pembelajaran di Program Studi
Pendidikan Agama Islam Fakultas Agama Islam UMSU dalam kegiatan pra tindakan, maka untuk menguji pengetahuan awal mahasiswa maka peneliti terlebih dahulu melaksanakan tes dengan mengujikan 10 soal pilihan ganda kepada mahasiswa mengenai materi evaluasi pembelajaran. Dari hasil evaluasi tersebut maka diperoleh hasil belajar mahasiswa pada materi evaluasi yang dilakukan sebagaimana dalam tabel berikut:

Tabel I. Hasil Belajar Pra Tindakan

\begin{tabular}{|c|c|c|c|}
\hline No & Nilai & F & \% \\
\hline 1 & $96-100$ & 0 & 0.0 \\
\hline 2 & $91-95$ & 0 & 0.0 \\
\hline 3 & $86-90$ & 0 & 0.0 \\
\hline 4 & $81-85$ & 2 & 8.3 \\
\hline 5 & $76-80$ & 4 & 16.7 \\
\hline 6 & $71-75$ & 4 & 16.7 \\
\hline 7 & $66-70$ & 4 & 16.7 \\
\hline 8 & $61-65$ & 4 & 16.7 \\
\hline 9 & $56-60$ & 5 & 20.8 \\
\hline 10 & $51-55$ & 0 & 0.0 \\
\hline 11 & $0-50$ & 1 & 4.2 \\
\hline \multicolumn{2}{|c|}{ Jumlah } & $\mathbf{2 4}$ & $\mathbf{1 0 0 . 0 0}$ \\
\hline
\end{tabular}

Berdasarkan tabel di atas, hasil perkuliahan mahasiswa dalam mata kuliah psikologi pendidikan pada materi evaluasi pembelajaran dalam penelitian tahap pra tindakan menunjukkan bahwa hanya 10 orang yang tuntas atau $(41,67 \%)$, dengan kriteria ketuntasan 
minimal yaitu nilai 75 , berarti belum memiliki ketuntasan klasikal, karena ketuntasan klasikal baru tercapai apabila $85 \%$ mencapai nilai 75 .

Kemudian dari hasil lembar observasi pada penelitian tahap pra tindakan terhadap motivasi mahasiswa dalam mata kuliah psikologi pendidikan materi pokok evaluasi pembelajaran, dapat diketahui sebagaimana dalam tabel berikut:

Tabel II. Motivasi Belajar Siswa Pada Pra Tindakan

\begin{tabular}{|c|c|c|c|}
\hline No & $\begin{array}{c}\text { Aspek Yang } \\
\text { Diamati }\end{array}$ & Skor & $\%$ \\
\hline 1 & Minat & 85 & 17.71 \\
\hline 2 & Perhatian & 82 & 17.08 \\
\hline 3 & Partisipasi & 82 & 17.08 \\
\hline 4 & Presentasi & 71 & 14.79 \\
\hline \multicolumn{2}{|c|}{ Jumlah } & 320 & 66.67 \\
\hline
\end{tabular}

Dari data uraian pada tabel di atas, maka motivasi belajar mahasiswa pada pra tindakan yang paling tinggi adalah aspek minat, yaitu $17,71 \%$, dan yang terendah adalah presentasi, yaitu 14,79\%. Namun secara umum presentase aspek yang ada dalam motivasi berada pada angka, yaitu $66,67 \%$. Artinya bahwa motivasi belajar mahasiswa, tergolong rendah. Untuk memecahkan masalah rendahnya hasil belajar mahasiswa dan untuk meningkatkan motivasi belajar mahasiswa pada Program Studi Pendidikan Agama Islam Fakultas Agama Islam UMSU, maka diupayakan dengan menggunakan model pembelajaran kooperatif group investigation.

\subsection{Deskripsi Hasil Penelitian}

\section{Siklus I}

\subsubsection{Perencanaan}

Dengan mengkaji kondisi proses perkuliahan yang terjadi, serta rendahnya motivasi dan hasil belajar mahasiswa. Untuk memperbaiki kelemahan tersebut, maka pada pelaksanaan siklus I dibuat perencanaan yaitu:

1) Menyusun Satuan Acara Perkuliahan SAP psikologi pendidikan dengan menerapkan Model Pembelajaran Kooperatif Group Investigation.

2) Mempersiapkan materi ajar, dengan materi evaluasi pembelajaran.

3) Menyiapkan media pelajaran yang tepat yang mendukung terhadap pelaksanaan pembelajaran.

4) Menyiapakan absensi, laporan pelaksanaan perkuliahan (LPP).

5) Menyusun instumen penelitian:

a) Perangkat soal evaluasi hasil belajar mahasiswa.

b) Lembar observasi aktivitas mahasiswa, yang bertujuan 
untuk melihat keadaan aktivitas mahasiswa dalam proses pembelajaran di kelas.

c) Lembar angket untuk mengetahui respon mahasiswa terhadap penggunaan Model Pembelajaran Kooperatif Group Investigation.

\subsubsection{Pelaksanaan Tindakan Siklus I} Pelaksanaan tindakan siklus I dilaksanakan pada hari Senin tanggal 19 Januari 2017, peneliti memulai siklus I pada pengenalan tentang materi evaluasi pembelajaran, dengan menerapkan Model Pembelajaran Kooperatif Group Investigation. Siklus I ini dilakukan selama 2 SKS. Kegiatan pembelajaran dilakukan sebagai berikut:

1) Kegiatan pendahuluan

a) Dosen membimbing mahasiswa untuk memulai pembelajaran dengan membaca basmalah. Melakukan apersepsi yaitu mengarahkan kesiapan mahasiswa untuk mengikuti pembelajaran kemudian memberikan motivasi dan informasi kompetensi yang akan dicapai oleh mahasiswa.

b) Dosen menjelaskan judul materi yang akan dibahas dalam perkuliahan, yaitu materi evaluasi pembelajaran. c) Menyebutkan standar kompetensi dan tujuan dari materi yang akan diajarkan.

d) Dosen menjelaskan indikator pencapaian keberhasilan pembelajaran yang ingin dicapai, yaitu menjelaskan pengertian evaluasi pembelajaran dalam psikologi umum.

2) Kegiatan inti

a) Dosen membagi mahasiswa ke dalam kelompok kecil yang terdiri dari \pm 5 orang mahasiswa.

b) Dosen mengajak mahasiswa melaksanakan investigasi, yaitu mahasiswa mencari informasi, menganalisis data, dan membuat kesimpulan. Dalam hal ini setiap anggota kelompok harus berkontribusi kepada usaha kelompok, bertukar pikiran, mendiskusikan, mengklarifikasi, dan mensintesis ide-ide;

c) Dosen memerintahkan kepada mahasiswa untuk membuat laporan akhir, yaitu dalam hal ini setiap kelompok merencanakan apa yang akan dilaporkan dan bagaimana membuat presentasinya dan membentuk panitia acara untuk mengoordinasikan rencana presentasi. 
d) Mahasiswa mempresentasikan laporan akhir.

3) Kegiatan penutup

a) Dosen membuat tes untuk mengetahui hasil belajar pada materi evaluasi pembelajaran tersebut.

b) Dosen membimbing mahasiswa untuk menutup pembelajaran dengan membaca hamdalah dan mengakhiri pembelajaran dengan mengucapkan salam.

\subsubsection{Hasil Siklus I}

Hasil pembelajaran mahasiswa yang telah mendapat perlakuan pembelajaran dengan menggunakan Model Pembelajaran Kooperatif Group Investigation. Pada siklus I, dapat dilihat pada tabel berikut:

\section{Tabel III. Hasil Belajar Mahasiswa Siklus I}

Berdasarkan tabel di atas, dapat diketahui bahwa hasil belajar mahasiswa dalam mata kuliah psikologi pendidikan materi evaluasi pembelajaran pada siklus I menunjukkan bahwa 22 orang yang tuntas atau (91.67\%) dan 2 orang mahasiswa yang belum tuntas atau $(8.33 \%)$.

Pada siklus I ini, hasil belajar mahasiswa telah mengalami peningkatan, dibandingkan dengan hasil yang didapat pada tahap pra tindakan. Dengan demikian, dikarenakan kriteria ketuntasan mahasiswa telah tercapai maka siklus di hentikan hanya sampai dengan siklus I saja.

Kemudian motivasi belajar mahasiswa pada siklus I, menunjukkan bahwa motivasi mahasiswa dalam mata kuliah psikologi pendidikan materi pokok evaluasi pembelajaran mengalami peningkatan dibandingkan dengan tahap pra tindakan, yaitu dapat dilihat dalam tabel di bawah ini:

Tabel IV. Motivasi Belajar

Siswa Pada Siklus I

\begin{tabular}{|c|c|c|c|}
\hline No & $\begin{array}{c}\text { Aspek Yang } \\
\text { Diamati }\end{array}$ & Skor & $\%$ \\
\hline 1 & Minat & 102 & 21.25 \\
\hline 2 & Perhatian & 105 & 21.88 \\
\hline 3 & Partisipasi & 101 & 21.04 \\
\hline 4 & Presentasi & 85 & 17.71 \\
\hline
\end{tabular}

\begin{tabular}{|c|c|c|c|}
\hline No & Nilai & $\mathbf{F}$ & $\%$ \\
\hline 1 & $96-100$ & 0 & 0.0 \\
\hline 2 & $91-95$ & 4 & 16.7 \\
\hline 3 & $86-90$ & 2 & 8.3 \\
\hline 4 & $81-85$ & 3 & 12.5 \\
\hline 5 & $76-80$ & 5 & 20.8 \\
\hline 6 & $71-75$ & 6 & 25.0 \\
\hline 7 & $66-70$ & 3 & 12.5 \\
\hline 8 & $61-65$ & 1 & 4.2 \\
\hline 9 & $56-60$ & 0 & 0.0 \\
\hline 10 & $51-55$ & 0 & 0.0 \\
\hline 11 & $0-50$ & 0 & 0.0 \\
\hline \multicolumn{2}{|c|}{ Jumlah } & 24 & 100.00 \\
\hline
\end{tabular}




\begin{tabular}{|c|c|c|}
\hline Jumlah & 393 & $\mathbf{8 1 . 8 8}$ \\
\hline
\end{tabular}

Dari data pada tabel di atas, maka motivasi belajar mahasiswa pada pra tindakan yang paling tinggi adalah aspek memperhatikan, yaitu $21,88 \%$, dan yang terendah adalah presentasi, yaitu $17,71 \%$. Namun secara umum presentase aspek yang ada dalam motivasi berada pada angka, yaitu $81,88 \%$. Artinya bahwa motivasi belajar mahasiswa pada mata kuliah psikologi pendidikan meningkat dengan menggunakan model pembelajaran Kooperatif Group Investigation.

\subsubsection{Refleksi Hasil Tindakan}

\section{Siklus I}

Refleksi dilakukan untuk menentukan apakah tindakan siklus I harus diulangi atau telah mencapai tingkat keberhasilan. Dalam pelaksanaan kegiatan belajar mengajar diperoleh informasi dari hasil pengamatan adalah:

1) Berdasarkan hasil tes akhir pada siklus I diperoleh data bahwa mahasiswa yang mendapat nilai tuntas 22 orang mahasiswa atau (91,67 \%), dengan demikian kriteria keberhasilan pembelajaran telah mencapai kriteria yang maksimal sebagaimana telah ditetapkan. Karena ketuntasan klasikal tercapai apabila $85 \%$ mencapai nilai KKM, yaitu nilai 75.

2) Dari hasil observasi terhadap motivasi mahasiswa dalam mata kuliah psikologi pendidikan materi pokok evaluasi pembelajaran dengan Model Pembelajaran Kooperatif Group Investigation, maka motivasi mahasiswa mengalami peningkatan dibandingkan dengan tahap pra tindakan, yaitu sebesar $81.88 \%$.

Dari uraian dan analisis data di atas, peneliti dapat menyimpulkan bahwa pembelajaran pada tindakan siklus I telah mencapai kriteria yang telah ditentukan yaitu persentase ketuntasan hasil belajar dan motivasi mahasiswa untuk belajar dengan Model Pembelajaran Kooperatif Group Investigation telah mencapai ketuntasan.

\subsection{Pembahasan Hasil Penelitian}

Berdasarkan paparan data di atas, dapat dikemukakan bahwa ada dua temuan secara umum dalam penelitian ini:

1. Hasil belajar mahasiswa Program Studi Pendidikan Agama Islam FAI UMSU mengalami peningkatan setelah menggunakan Model Pembelajaran Kooperatif Group Investigation, yaitu hasil 
belajar mahasiswa pada kegiatan pra tindakan hanya 10 orang mahasiswa yang mendapat nilai tuntas atau mencapai $41,67 \%$. Sedangkan pada siklus I hasil belajar mahasiswa mengalami peningkatan dibandingkan dengan kegiatan pra tindakan, yaitu mencapai 22 orang mahasiswa yang mendapat nilai tuntas atau mencapai 91,67\%, dengan demikian kriteria keberhasilan pembelajaran telah mencapai kriteria yang maksimal sebagaimana telah ditetapkan pada siklus I. Karena ketuntasan klasikal tercapai apabila $85 \%$ mencapai nilai KKM, yaitu nilai 75.

2. Motivasi mahasiswa dalam mata kuliah psikologi pendidikan materi pokok evaluasi pembelajaran dengan Model Pembelajaran Kooperatif Group Investigation, mengalami peningkatan di bandingkan pada tahap pra tindakan, yaitu $81,88 \%$.

Dengan demikian melihat hasil tersebut, penelitian tindakan kelas sangat bermanfaat, sehingga setiap pendidik yang ingin meningkatkan kualitas pembelajarannya di kelas maka perlu adanya inovasi yang dilakukan oleh pendidik itu sendiri, baik mengenai strategi yang dipakai atau metode yang diterapkannya apakah sudah tepat atau belum. Hal inilah yang terkadang menjadi kendala bagi dosen di dalam melaksanakan pembelajaran di kelas, sehingga mahasiswa tidak termotivasi untuk belajar dengan baik di dalam meningkatkan kemampuan atau prestasi belajarnya. Dengan demikian penelitian tindakan kelas ini terbukti telah dapat meningkatkan motivasi dan hasil belajar mahasiswa dalam materi evaluasi pembelajaran.

\section{E. KESIMPULAN DAN SARAN}

\subsection{Kesimpulan}

Berdasarkan hasil dan analisis data hasil penelitian yang telah dijelaskan pada bab sebelumnya, maka dapat dikemukakan kesimpulan penelitian ini, yaitu sebagai berikut:

1. Hasil belajar mahasiswa Program Studi Pendidikan Agama Islam FAI UMSU mengalami peningkatan setelah menggunakan Model Pembelajaran Kooperatif Group Investigation, yaitu hasil belajar mahasiswa pada pra tindaan hanya 10 orang mahasiswa yang mendapat nilai tuntas atau mencapai $41.67 \%$. Sedangkan pada siklus I hasil belajar mahasiswa mengalami 
peningkatan dibandingkan dengan kegiatan pra tindakan, yaitu mencapai 22 orang mahasiswa yang mendapat nilai tuntas atau mencapai 91,67\%.

2. Sedangkan motivasi mahasiswa terhadap pembelajaran dengan menggunakan Model Pembelajaran Kooperatif Group Investigation. Pada materi evaluasi pembelajaran di Program Studi Pendidikan Agama Islam FAI UMSU menunjukkan kondisi positif dan menggembirakan. Hal ini ditunjukkan dari hasil observasi yang dilakukan pada mata kuliah psikologi pendidikan materi pokok evaluasi pembelajaran dengan Model Pembelajaran Kooperatif Group Investigation, yaitu motivasi mahasiswa mengalami peningkatan di bandingkan pada tahap sebelumnya, yaitu mencapai $81,88 \%$.

\subsection{Saran}

Berdasarkan hasil uraian Penelitian Tindakan Kelas (PTK) ini, dan beberapa kesimpulan yang telah diutarakan di atas, ada sejumlah pemikiran yang penulis sarankan yang diharapkan berguna bagi dosen dalam menjalankan fungsinya dan pihak- pihak yang terkait dalam pendidikan, di antaranya:

1. Dengan memperhatikan hakikat dan sifat Model Pembelajaran Kooperatif Group Investigation. Sangat berguna untuk meningkatkan motivasi dan hasil belajar mahasiswa, maka disarankan kepada dosen supaya memahami metode pembelajaran dengan meningkatkan kualitas diri, baik dengan cara belajar atau dengan mengikuti pelatihanpelatihan peningkatan mutu, untuk kemudian diterapkan dalam proses pembelajaran pada mata pelajaran dan aspek yang tepat.

2. Kepada dosen agar dapat meningkatkan kompetensi dalam mengajar dengan melakukan Penelitian Tindakan Kelas (PTK), sehingga akan ditemukan suatu kondisi belajar yang efektif dan meningkatkan hasil belajar khususnya mahasiswa.

3. Rancangan pembelajaran yang dilakukan dalam penelitian tindakan kelas ini belum sepenuhnya sempurna, untuk itu bagi dosen lain yang ingin mengimplementasikannya dalam materi evaluasi pembelajaran atau pada materi yang lain hendaknya 


$\begin{array}{lccr}\text { menelaah terlebih dahulu, } & \text { Arifin, Z. (2012). } & \text { Evaluasi } \\ \text { sehingga dapat menerapkannya } & \text { Pembelajaran. } & \text { Jakarta: } \\ \text { dengan lebih baik. } & \text { Direktorat Jendral Pendidikan } \\ \text { Pengambil kebijakan, kiranya } & \text { Islam Kementrian Agama. }\end{array}$
selalu mencari solusi untuk meningkatkan kualitas dosen agar mampu mengajar secara profesional dengan memberikan pelatihan-pelatihan secara bertahap dan kontinuitas, sehingga para dosen bisa lebih menguasai model, strategi dan metode belajar yang efektif, juga berusaha melengkapi media pembelajaran sehingga memudahkan dosen menyampaikan materi pelajaran.

Dalam rangka mencapai tingkat ketepatan penerapan Model Pembelajaran Kooperatif Group Investigation. dalam proses pembelajaran yang lebih inovatif, maka penelitian ini perlu dilanjutkan dengan materi dan pelajaran yang berbeda dan kompetensi yang berfokus pada pendalaman pemahaman, dan keluasan wawasan.

\section{DAFTAR PUSTAKA}

Anni, C. T. (2004). Psikologi Belajar. Semarang: UPT UNNES Press. 
Nasution, A.-R. d. (2011). Teori

Belajar dan Pembelajaran .

Medan: Perdana Publising.

Nasution, S. (2003). Berbagai

Pendekatan dalam Proses

Belajar Mengajar. Jakarta:

Bumi Aksara.

Nurdin, S. (2005). Model

Pembelajaran yang

Memperhatikan Keragaman

Individu Siswa dalam

Kurikulum Berbasis

Kompetensi. Ciputat: Quantum

Teaching.

Purwanto, M. N. (2005). Prinsip-

Prinsip dan Teknik Evaluasi

Pengajaran.

Bandung:

Rosdakarya.

Purwanto, N. (2004). Psikologi

Pendidikan. Bandung: Remaja

Rosdakarya.

Ramayulis. (2008). Metodologi

Pendidikan Agama Islam.

Jakarta: Kalam Mulia.

Rosnita. (2007). Evaluasi Pendidikan.

Bandung: Ciptapustaka Media.

Rusman. (2010).Model-Model

Pembelajaran. Jakarta: PT.

Raja Grafindo Persada.

Sanjaya, W. (2008). Strategi

Pembelajaran: Berorientasi

Standar Proses Pendidikan.
Jakarta: Kencana Prenada

Media Group.

Sardiman A.M. (2001).Interaksi dan Motivasi Belajar mengajar. Jakarta: Rajawali Press.

Soemanto, W. (2003). Psikologi Pendidikan. Jakarta: PT. Rineka Cipta.

Sudarsono. (2005). Kamus Filsafat dan Psikologi . Jakarta: Rineka Cipta.

Sudjana, N. (2005). Penilaian Hasil Proses Belajar Mengajar. Bandung: PT. Remaja Rosdakarya.

Sumarmi. (2012). Model-Model Pembelajaran Geografi. Malang:

Aditya Media.

Uno, H. B. (2008). Teori Motivasi dan Pengukurannya: Analisis Di Bidang Pendidikan . Jakarta: Bumi Aksara.

Uno, H. B. (2010). Model Pembelajaran: Menciptakan Proses Belajar Yang Efektif dan Kreatif. Jakarta: Bumi Aksara.

Winataputra. (2005). Perkembangan Peserta Didik. Jakarta: Universitas Terbuka Depdiknas. 